\section{Soviet schools tied closer to technology}

THE relationship between science and the needs of the national economy is a matter of constant theoretical discussion among the Soviet planners. So too is the relationship between education and the demands of expanding technological growth. The latest decree of the Central Committee of the CPSU and the Supreme Soviet on the further improvement of secondary education reflects a new concern with these problems.

The current doctrine stresses that science must serve the needs of the national econotny-with Brezhnev's famous caveat that "there is nothing more practical than a good theory!". Even interplanetary probes are announced to have been launched "in accordance with the needs of the national economy". During the last few years, several scientific bodies-for example, the Far Eastern Science Centre-have been publicly censured for failing to orientate their research to the immediate needs of production. The closer coordination of research and the needs of industry is a matter of pressing concern, and has led to the establishment of various problem solving institutes closely linked to production enterprises in their areas.

Not surprisingly, therefore, the new decree on education extends the same process to the secondary school level. Referring to the "Leninist" principle of a "single, labouring, polytechnic school", the decree notes that, at present, school-leavers' skills and outlook do not correspond "to the requirements of social production and scientific and technical progress". The decree continues "Many school leavers go out into the world without the necessary preparation for work, without sufficient information about the basic professions of the masses, and they experience difficulties in the transition to working for the national economy".

This stress on preparation for work suggests a return to the Khrushchev era, when parties of school-children, carrying out what was officially described as "labour training" in factory and collective farm, succeeded only in antagonising and disrupting the workers, who grumbled that they were expected to act as unpaid nursemaids, in addition to their official duties. In fact, however, little is being done on these lines. After the fall of Khrushchev, labour training was quietly phased out except in senior classes; the present decree urges only that pupils of the ninth and tenth classes (16 to 18 years old) should have their "labour training" increased from two to four hours per week (within the limits of the timetable) and that this training should correspond to the facilities and I'm not sure whether to fail him or give needs of local production. Special emphasis is placed on vocational training, especially for those leaving after the eighth class (Soviet compulsory education was officially extended to ten classes some years ago, and it is interesting that the option of leaving after eight years has still not been completely

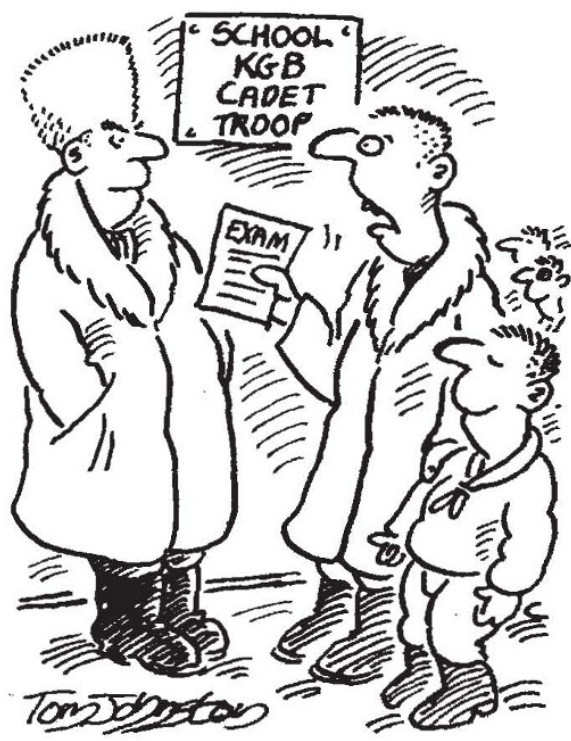

Vanya has stolen the exam questions! him an ' $A$ '!

\section{Japan makes new study of its science}

JAPAN's total R\&D expenditures rank as fourth largest in the world, according to the latest figures released by the Japanese government in a white paper on science and technology, but net growth has ceased, once inflation is taken into account. Total expenditures for fiscal 1975 (the last year for which most figures are given) were 2,622 billion yen, roughly equal to $\$ 8.8$ billion or $£ 4.0$ billion at that time. This figure was about a quarter the expenditures of the United States and one-third those of the Soviet Union for R\&D that year, placing Japan just behind West Genmany and just ahead of France. Net expenditures were $2.7 \%$ higher in 1975 than 1970, but they peaked in 1973.

Expressed as a proportion of the national economy, Japan's R\&D expenditures were $2.06 \%$ of the gross national income, compared to $4.8 \%$ for the Soviet Union and $2.55 \%$ for the United States. The most important comparison to other countries, however, involves identifying the source of these funds. Government expenditures account for only about a quarter of the total in Japan, compared to nearly half the total in most other developed countries. A much larger proportion of phased out).

Shortcomings in syllabuses and textbooks are stressed; in a number of cases, it is said, these are overloaded with "superfluous information and matters of secondary importance". The proposed changes will ensure that courses include the necessary amounts of the rudiments of the sciences with information on the relationship of the subjects studied to the needs of the economy. At the same time, the total work-load of pupils is to be decreased to 24 hours in the first to third classes, rising gradually to 32 hours in the tenth class. Excessive homework is to be eliminated.

Vocational guidance will become the special responsibility of an Interdepartmental Methodological Council of the Ministry of Education, with a "base enterprise (organisation)" attached to every school.

An increase in the direction of young university graduates into school teaching is envisaged; in compensation, however, the title of "People's Teacher of the USSR" has been established for those who distinguish themselves in the field of education.

Finally, and perhaps most important, school children will at last receive free textbooks loaned to them by the school, and special funds are to be allotted to enable the schools to buy the necessary book stocks.

research is thus funded by private industry, which profoundly affects the nature of projects undertaken. Corporations, for example, spend more than three times as muoh on R\&D as either universities or research institutes.

As one would expect, this private funding produces a heavy bias in favour of what would be called applied research and development, in the West. However, this tendency is not readily apparent when one first examines the figures of the white paper-theoretically Japan spends $14.2 \%$ of its soience and technology funds for basic research, compared to $12.9 \%$ in the United States and $8.0 \%$ in the United Kingdom. A better understanding of this paradox emerges after examination of other government documents to find what sorts of projects are included under the definition of "basic" research. Many of the areas involved, such as materials development, do indeed require investigation for longer periods than one might ordinarily consider reasonable for "applied" research, but a specific commercial application is usually envisaged. Even by their own definition, however, the Japanese are rapidly decreasing the proportion of 
funding devoted to basic research.

The distribution of manpower among various sectors parallels the division of funds, with corporations employing substantially more researchers and technicians than both universities and research institutes combined. For the calendar year 1976, total Japanese R\&D manpower was 488,000 , divided into $53.3 \%$ researchers, $16.2 \%$ assistant researchers, and $18.3 \%$ technicians. If one allows for differences in defining "researcher", the number of scientists and engineers is about half that in the United States and three times that in the United Kingdom.

Since much of the technological underpinning of Japan's most successful industries has been borrowed and adapted from abroad, a recurring theme of recent science policy statements has been the need to improve domestic research so that more in- novations could be produced in Japan. One indication of progress has been a strong positive shift in Japan's 'balance of patents', with more Japanese applying for patents abroad than foreigners applying for patents in Japan. But a more important figure is the balance of cost between buying and selling rights to technology, and here Japan runs a large and increasing deficit. Using after-tax figures for all enterprises involved in such trade, 1976 receipts were only $20.4 \%$ of sales, down from $22.6 \%$ the year before. Clearly Japan remains strongly dependent on research conducted in other countries for much of its industrial technology.

Finally, when comparing Japanese research to that of other countries, the question of professional salaries is often brought up, only to degenerate into a welter of contradictory statements. Interviews with the officials of the
Science and Technology Agency who produced the white paper provide the following basis for limited comparison. In 1976 a 40-year-old researcher had an average monthly income of 225,538 yen, then equivalent to about $\$ 760$, including some overtime. A base annual salary would thus come to $\$ 9,125$, but to this must be added a lump-sum "bonus" of nearly six months" wages, bringing the total to $\$ 13,687$. Since Japanese income taxes are quite low for this salary range, the researcher's after-tax income would be equivalent to that of an American or European with substantially higher gross wages. But since pensions in Japan are substantially less than those abroad, the researchers would have to set aside more of his income for retirement, which generally comes at a younger age than for his foreign colleagues.

John Douglas
THE dispute about gene-splicing typifies some of the current hostility towards science. There is one important exception: gene-splicing dangers are purely theoretical. Recombinant DNA has never been accused of producing a tumour in the bladder of a rat, or of making a brown pelican lay a soft-shelled egg. Nevertheless, the rank-and-file defenders of the environment respond to the summons of their leaders, and sally forth to do battle with the mysterious shadows of manipulated molecules that could envelop and ruin our 'space-ship Earth'. Three billion years of organic evolution will be like an evening we are told, when the fantastic new life-forms escape from the test-tubes.

Perhaps so. In any case, I have been fascinated by the eagerness with which lawyers, clergy, and lawmakers enter the dispute. It was to be expected that the issue would be seized by bureaucracies for purpose of selfproliferation. There were good precedents. The return of predictably lifeless rocks from the surface of the moon gave rise to a scramble for authority as to who should shield us from the dangers of contamination. The officials in charge of plant quarantine demanded that the samples be tested for wheat-rust spores.

The more successful assaults on technology are based on projected rather than actual hazards. The real catastrophes don't seem to be as interesting. Dams collapse and many people are drowned. These tragedies are soon forgotten, and dams for hydroclectric power continue to bc built. Plutonium is a better target; it is new, it is dreadful, and it must be exorcised-just in case. Cigarettes kill thousands with lung cancer and emphysema, but advertisements in the United States still assail us with

\section{Wandering minstrels}

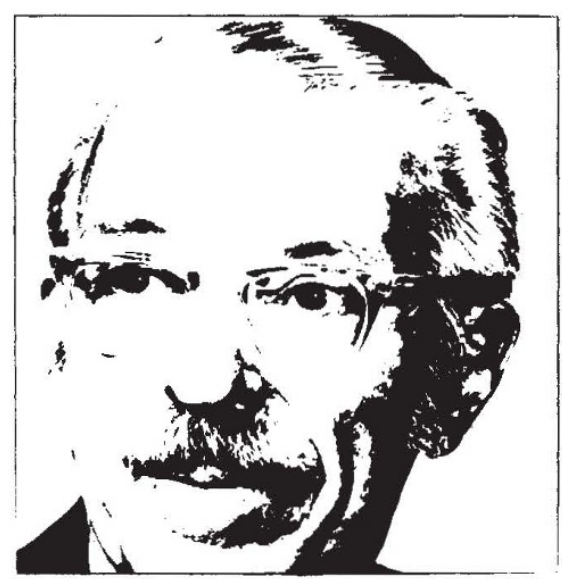

THOMAS H. JUKES

gigantic pictures of nicotine-loving cowboys and liberated women smokers. Currently, the carcinogen of interest at the US Department of Agriculture is bacon, not subsidised tobacco.

The most unusual of all targets is the phantom menace of geneticallyengineered organisms; a legislated, institutionalised and regulated figment of the imagination. People who know least about DNA are the most eloquent among those who fear it. They don't quote Jim Watson, who, on the subject of recombinant
DNA, was reported to have said recently: "Science is good for society. We are being attacked by everyone who doesn't have the guts to go ahead. The dangers of this thing are so slight-you might as well worry about being licked by a dog".

$\mathrm{He}$ was too late. The molecular biologists did themselves in at Asilomar. After this, it was a foregone conclusion that DNA would be placed under official guidelines. Like a layer of molasses, the non-ebbing tide of regulations has crept over the field of gene-splicing. How can a danger ever become trivial if the livelihood of an echelon of bureaucrats depends on writing rules to cope with it? The officials now need to demonstrate their public zeal.

In The Mikado, the Emperor of Japan is angry because there haven't been any executions lately in the town of Titipu. A victim must be found, or, by imperial decrec, Titipu will be reduced to the level of a hamlet. So the civic leaders schedule a simulated beheading for a wondering minstrel, Nanki-Poo.

Recently, in Boston, a victim was apparently needed to show that the National Institutes of Health guidelines on gene-splicing were being cnforced. The prototypic Nanki-Poo was Charlie Thomas, who had been caught red-handed for filing a document too late. Watson was unkind enough to liken such infractions, when committed knowingly, to "cheating at tiddlywinks", but this particular sin seems to have been inadvertent. Anyway, Boston was saved, and let us hope that, like Nanki-Poo, Thomas will escape from the Lord High Executioner. 